\title{
Cyclin D1 and retinoblastoma protein expression in oesophageal squamous cell carcinoma
}

\author{
Runjan Chetty, Serisha Chetty
}

\begin{abstract}
Aims-To assess the immunoexpression of cyclin D1 and retinoblastoma in a cohort of oesophageal squamous cell carcinoma cases from South Africa to see whether there is a relation between these two proteins. In addition, protein expression was correlated with clinicopathological features.
\end{abstract}

Methods-Fifty biopsies and 30 oesophagectomy specimens were immunostained with commercially available antibodies to cyclin D1 and retinoblastoma proteins, following microwave antigen retrieval.

Results-Twenty three of the 80 cases (29\%) showed cyclin D1 protein expression. However, only five cases had $>50 \%$ of the tumour cells displaying immunopositivity. Three of the four cases with lymph node spread were cyclin D1 positive in the primary tumour and the metastasis. Fifty three cases were immunoreactive with the antiretinoblastoma antibody; 29 of these cases showing $>50 \%$ of cells with immunolabelling. Of the 23 cyclin D1 positive cases, 18 were also retinoblastoma positive. No correlation was observed between cyclin D1 and retinoblastoma protein expression and age, sex, race, or histological grade.

Conclusions-Cyclin D1 is expressed in a minority of cases of oesophageal squamous carcinomas from South Africa. However, three of four cases with lymph node spread were cyclin D1 positive, thus indicating that cyclin D1 positive tumours may have a greater propensity for spread. In addition, 18 of 23 cyclin $D 1$ positive cases also expressed retinoblastoma protein. These findings suggest a possible relation between cyclin D1 and retinoblastoma proteins in a proportion of cases of oesophageal squamous.

(f Clin Pathol: Mol Pathol 1997;50:257-260)

Keywords: cyclin D1; retinoblastoma; squamous carcinoma; oesophagus

Department of

Anatomical Pathology, University of Natal

School of Medicine,

Private Bag 7,

Congella 4013,

Durban, South Africa

Correspondence to:

Professor R Chetty.

Accepted for publication 28 August 1997 because the pathogenesis of oesophageal squamous cell carcinoma shows geographical variation. In Europe and North America, cigarette smoking and alcohol abuse are major risk factors, while in Central Asia, China, and Africa dietary factors, either together or in isolation, play more of a pathogenetic role. ${ }^{1}$

Multiple genetic changes, which result in abnormalities of the cell cycle, occur during the process of carcinogenesis. The normal cell cycle has a number of positive and negative feedback loops, with several proteins playing important checkpoint roles. Among these proteins are the cyclin and retinoblastoma proteins, which act in concert to maintain the integrity of the normal cell cycle. It has been suggested that increased concentrations of the cyclin D1 protein abrogate the tumour suppressor activity of retinoblastoma protein, thus allowing cells with damaged DNA to replicate. ${ }^{2}$

Therefore, this study was directed at establishing the cyclin D1 and retinoblastoma protein $(\mathrm{pRb})$ status in oesophageal squamous cell carcinoma from South Africa, and to see if there was a relation between these protein levels and clinicopathological features.

\section{Methods}

The surgical records of the department of anatomical pathology, University of Natal School of Medicine and King Edward VIII Hospital, covering a nine year period, were searched for cases of oesophageal squamous cell carcinoma. From these, 50 biopsies and 30 oesophagectomy specimens were included in this study. There was sufficient material in the biopsies to assess histological differentiation, and surface dysplasia was also present in 33 of the specimens. The TNM status of the oesophagectomy specimens was determined. The patients' age, sex, and race were also obtained.

All specimens were fixed in $10 \%$ buffered formalin and processed in a routine fashion. Immunohistochemistry was performed on the formalin fixed, paraffin wax embedded tissue.

Sections $(3 \mu \mathrm{m})$ were picked up on to polyL-lysine coated slides and incubated for 10 minutes at $60^{\circ} \mathrm{C}$. Sections were cleared through xylene and rehydrated with descending grades of alcohol. Microwave antigen retrieval was accomplished by placing slides in $0.01 \mathrm{M}$ buffered sodium citrate at $\mathrm{pH} 6.0$ at $85^{\circ} \mathrm{C}$ for 10 minutes in a $\mathrm{H} 2500$ microwave processor (Energy Beam Sciences, Massachusetts, USA). After microwaving, sections were cooled for 10 minutes. After transfer through two changes of PBS at region. While the genetics of oesophageal squamous cell carcinoma from China and the Far East have been investigated fairly extensively, cases from South Africa remain relatively unexplored. The examination of cases from different parts of the world is warranted 
$\mathrm{pH}$ 7.4, the slides were incubated in $3 \% \mathrm{H}_{2} \mathrm{O}_{2}$ at room temperature for five minutes. The sections were incubated with antibodies to cyclin D1 (clone P2D11F11, dilution 1:20; Novocastra Laboratories, Newcastle upon Tyne, UK) and $\mathrm{pRb}$ (antiretinoblastoma protein, dilution 1/50; Zymed Laboratories, California, USA) for four minutes in a domestic microwave oven (Sharp Carousel, R7280, $650 \mathrm{~W})$. The sections were then incubated with biotinylated link antibody in the microwave oven at $10 \%$ power output for three and a half minutes. After washing in PBS, sections were incubated with peroxidase labelled streptavidin in the microwave oven for three and a half minutes. Sections were then incubated with the substrate chromogen diaminobenzidine (DAB) and, after washing with distilled water, counterstained with Mayer's haematoxylin for three minutes. Finally, sections were rinsed in ammoniated water, rinsed in running tap water, dehydrated in alcohol and xylene, and coverslipped with DPX.

All negative cases were repeated, and appropriate positive controls (a case of breast cancer known to be cyclin D1 positive and lymphocytes from a reactive lymph node for $\mathrm{pRb}$ ) were run in parallel. Omission of the primary antibody was used for negative controls. Nuclear immunolabelling was regarded as a positive reaction. The anti-pRb antibody detects both hypophosphorylated and hyperphosphorylated protein.

Scoring of immunoreactivity was performed as follows: the numbers of positive nuclei in a high power field were divided by the total numbers of nuclei present in that field, and this was expressed as a percentage. All the cells in the biopsies were counted, while 25 to 50 high power fields were assessed in the resection specimens, depending on the amount of tumour represented on a particular slide. A mean of the number of fields counted was then taken. An arbitrary score was assigned as follows: negative, $<5 \%$ positivity; $+1,6-25 \%$ positivity; $+2,26-50 \%$ positivity; $+3,>50 \%$ positivity.

Statistical analysis was performed using the $\chi^{2}$ and Fisher's exact tests; $p$ values $<0.05$ were deemed significant.

\section{Results}

CLINICAL DETAILS

The patients ranged in age from 28 to 80 years. Twenty seven of the 80 cases were women. Only two Asians and one white patient were encountered in this study, the remaining patients were black.

\section{LIGHT MICROSCOPY}

All cases were squamous cell carcinomas of the oesophagus: 36 were well differentiated, 18 were moderately differentiated, and 26 were poorly differentiated tumours. Dysplastic epithelium was present in 33 of the biopsies and in all of the oesophagectomy specimens. The dysplastic epithelium tended to arise abruptly when compared to normal mucosa. Peritumorous lymphatic invasion was

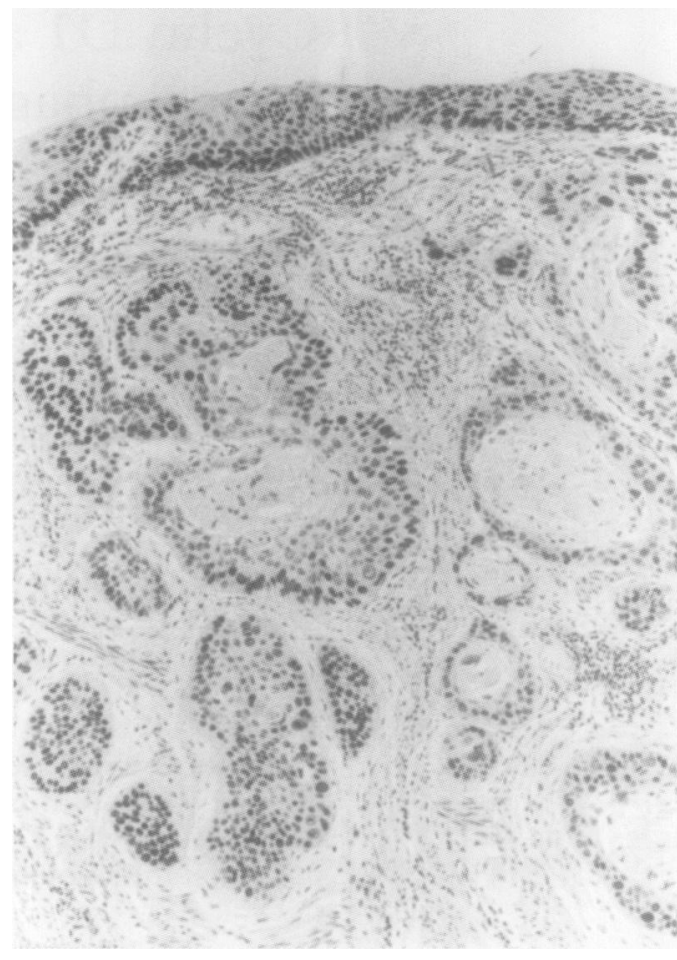

Figure 1 Cyclin D1 expression in dysplastic squamous epithelium and an invasive squamous carcinoma. Basal cells and those located in the middle third of the epithelium show the most cyclin D1 positivity. Occasional superficial cells are also immunoreactive. In the invasive component, more than $50 \%$ of the tumour cells are immunopositive.

identified histologically in nine cases. The TNM staging of the oesophagectomy specimens was as follows: two cases were $\mathrm{T} 1 \mathrm{N0}$ M0; 13 cases were T2 N1 M0; 15 cases were T3 N3 M2.

\section{IMMUNOHISTOCHEMISTRY}

\section{Cyclin D1}

Only 23 of the 80 cases (29\%) were positive. All positive cases showed nuclear positivity, with two cases showing both nuclear and cytoplasmic immunoreactivity. Of these 23 cases, in 8 only five were $>50 \%$ of the tumour cells $(+3)$ positive (fig 1). In the positive tumours, 9 occasional cells in the accompanying dysplastic epithelium were positive. Some of these were basal in location, although most occupied the middle third of the mucosa, with occasional positive cells being found more superficially (fig 1). Of the four cases with lymph node spread, three were cyclin D1 positive. The lymph node metastases in these three cases also showed cyclin D1 positive tumour cells. The other case with lymph node spread was negative in both primary and secondary sites.

No statistically significant correlation was found between cyclin D1 expression and histological grade, age, sex, or race.

\section{Retinoblastoma protein}

Fifty three cases (66.25\%) showed pRb immunopositivity (fig 2 ). Twenty nine of these cases showed +3 immunopositivity. Occasional basal cells in the normal mucosa were $\mathrm{pRb}$ positive. The staining in dysplastic epithelium tended to parallel the intensity seen in the invasive tumour. All four cases with lymph node spread showed $\mathrm{pRb}$ 


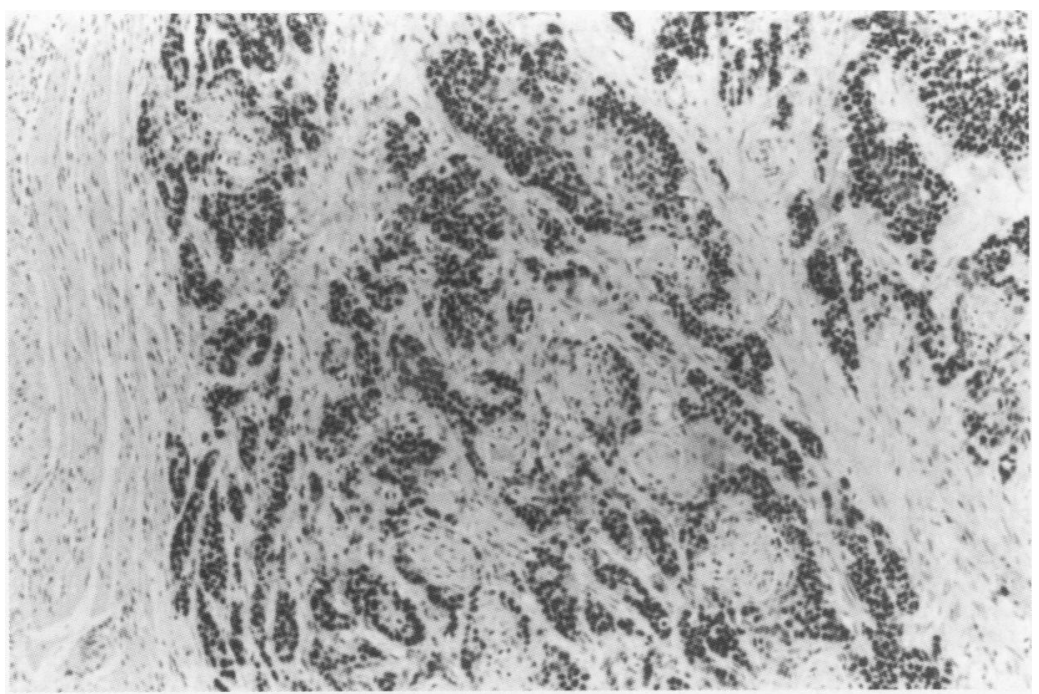

Figure 2 Intense nuclear positivity for retinoblastoma protein in an invasive squamous carcinoma.

immunopositivity in both the primary tumour and metastases. Once again, no correlation was found between $\mathrm{pRb}$ immunoexpression and any clinicopathological parameter.

Cyclin D1 versus $p R b$

Of the 23 cyclin D1 positive cases, only five were negative for $\mathrm{pRb}(\mathrm{p}<0.05)$.

\section{Discussion}

The retinoblastoma gene, located on chromosome $13 \mathrm{q} 14$, is considered to be a prototypic tumour suppressor gene. It is composed of 27 exons and encodes a nuclear phosphoprotein of $105-110 \mathrm{kDa}(\mathrm{pRb})$. The protein has several phosphorylation sites, is associated with DNA binding, is an important cell cycle regulator, and plays a role in differentiation. ${ }^{3} \mathrm{pRb}$ is expressed in a wide range of tumours. ${ }^{4-9}$ The concentrations of $\mathrm{pRb}$ remain the same throughout the cell cycle; however, its state of phosphorylation is cycle dependent and it is a target for the enzymatic activity of cyclin and cyclin dependent kinases. ${ }^{9} \mathrm{pRb}$ is in the underphosphorylated form in the $G_{1}$ phase of the cell cycle. It becomes phosphorylated when the cycle progresses into late $G_{1}$ and the early $S$ phase, and this lasts into $G_{2}$. pRb is undetectable by immunohistochemistry during $G_{0}$ to middle $G_{1}$ phases, and then there is a 10 -fold increase during $\mathrm{G}_{2}-\mathrm{M}$. $^{10}$

Chromosome $11 \mathrm{q} 13$ contains a cluster of genes (hst, int 2 , bcl-1, and cyclin D) that are often coamplified as a unit or amplicon. The cyclin D1 gene is considered to be the most important of these and the cyclin D1 protein is expressed in the $G_{1}$ phase of the cell cycle. Overexpression of the cyclin D1 protein has been seen in breast, gastric, and oesophageal carcinomas. ${ }^{11}$

The checkpoint controlling entry into the S phase of the cell cycle is important because it prevents replication of cells with damaged DNA. Targets for the $\mathrm{G}_{1}-\mathrm{S}$ checkpoints are the cyclins, especially cyclin D1 which has an interdependent relation with $\mathrm{pRb} .{ }^{11}{ }^{12}$ Cyclin D1 regulates the level and phosphorylation status of $\mathrm{pRb}$ so that cells can enter $\mathrm{S}$ phase and replicate. ${ }^{11}$

In a study of oesophageal squamous cell carcinoma from China, France, and Italy it was shown that the cyclin D1 gene was amplified in $30 \%$ of cases. ${ }^{2}$ Furthermore, all those cases with amplification of the gene showed increased cyclin D1 protein expression. In the same study, $\mathrm{pRb}$ expression was demonstrated by immunohistochemistry in $83 \%$ of the squamous cell carcinomas examined. Of interest, all the cases overexpressing cyclin D1 protein also showed $\mathrm{pRb}$ expression. ${ }^{2}$

In another study, amplification of the cyclin D1 gene was seen in $23 \%$ of cases and was associated with shorter survival periods. ${ }^{13}$ This particular group did not look at cyclin D1 protein expression. Naitoh and colleagues examined 55 cases of formalin fixed, paraffin wax embedded oesophageal squamous cell carcinoma from Japan for cyclin D1 protein expression. $^{14}$ Cyclin D1 was expressed strongly by $38.1 \%$ of their cases, and this was associated with poor survival. Two other studies have shown relatively high levels of cyclin D1 protein expression in oesophageal squamous cell carcinoma. Sheyn and colleagues, ${ }^{15}$ using the same antibody as this current study, showed that 17 out of 20 cases were cyclin D1 immunopositive. However, only eight of these 17 cases contained between $40-75 \%$ positive cells. Adelaide $e t$ al $^{16}$ demonstrated cyclin D1 immunoreactivity in $63 \%$ of their cases. Both of these studies found a good correlation between the immunohistochemical detection of the cyclin D1 protein and amplification of the gene.

The current study has shown that $29 \%$ of cases of squamous cell carcinoma from South Africa are cyclin D1 protein positive, while $66.25 \%$ of the cases are $\mathrm{pRb}$ positive. All but five of the cyclin D1 positive cases coexpressed both proteins. These figures are slightly less than that seen in squamous cell carcinoma of the oesophagus in other high risk regions. Although the disparity may reflect true geographical and epidemiological differences, it must be borne in mind that cyclin D1 and $\mathrm{pRb}$ protein detection was achieved by immunohistochemistry which has some limitations, and negative immunostaining does not preclude the presence of very small amounts of protein. From these results it would appear that overexpression of cyclin D1 protein occurs in a minority of oesophageal squamous cell carcinomas from South Africa. Three of the four cases with nodal involvement were cyclin D1 positive in the primary and metastatic site. The majority of oesophageal squamous cell carcinomas that were cyclin D1 positive also showed immunoexpression of $\mathrm{pRb}$. Thus, the postulate that cyclin D1 overexpression abrogates the normal inhibitory role of $\mathrm{pRb}$ by inducing phosphorylation may well be operative in a certain proportion of cases.

Runjan Chetty is supported by a University of Natal Research Fund grant. 
1 Stemmermann G, Heffelfinger SC, Noffsinger A, Zhong Y, Miller MA, Fenoglio-Preisser CM. The molecular biology of esophageal and gastric cancer and their precursors oncogenes, tumor suppressor genes, and growth factors. Hum Pathol 1994;25:968-81.

2 Jiang W, Zhang Y-J, Kahn SM, Hollstein MC, Santella RM $\mathrm{Lu} \mathrm{S}-\mathrm{H}$, et al. Altered expression of the cyclin D1 and retinoblastoma genes in human esophageal cancer. Proc Natl Acad Sci USA 1993;90:9026-30.

3 Lee W-H, Shew J-Y, Hong FD, Sery TW, Donoso LA, Bookstein $\mathrm{R}$, et al. The retinoblastoma susceptibility gene Bookstein $\mathrm{R}$, et al. The retinoblastoma susceptibility gene
encodes a nuclear phosphoprotein associated with DNA binding activity. Nature 1987;329:642-5.

4 Cordon-Cardo C, Wartinger D, Petrylak D, Dalbagni G, Fair WR, Fuks Z, et al. Altered expression of the retinoblastoma gene product: prognostic indicator in bladder cancer. 7 Natl Cancer Inst 1992;84:1251-6.

5 Cordon-Cardo C, Richon VM. Expression of the retinoblastoma protein is regulated in normal human tissues. $A m$ f Pathol 1994;144:500-10.

6 Constancia M, Seruca R, Carneiro F, Silva F, Castedo S. Retinoblastoma gene structure and product expression in human gastric carcinomas. Br f Cancer 1994;70:1018-24.

7 Cance WG, Brennan MF, Dudas ME, Huang C-M, Cordon-Cardo C. Altered expression of the retinoblastoma gene product in human sarcomas. $N$ Engl f Med 1990;323: 1457-62.

8 Holm R, Nesland JM. Retinoblastoma and p53 tumour suppressor gene protein expression in carcinomas of the thyroid gland. $\mathcal{F}$ Pathol 1994;172:267-72.
9 Martinez JC, Piris MA, Sanchez-Beato M, Villuendas R, Orradre JL, Algara $\mathrm{P}$, et al. Retinoblastoma (Rb) gene product expression in lymphomas. Correlation with $\mathrm{Ki} 67$ growth fraction. F Pathol 1993;169:405-12.

$10 \mathrm{Xu} \mathrm{H}-\mathrm{J}, \mathrm{Hu} \mathrm{S}-\mathrm{X}$, Benedict WF. Lack of nuclear RB protein staining in $G_{0} /$ middle $G$, cells: correlation to changes in total Rb protein level. Oncogene 1991;6:1139-46.

11 Hunter T, Pines J. Cyclins and cancer II: cyclin D and CDK inhibitors come of age. Cell 1994;79:573-82.

12 Hartwell LH, Kastan MB. Cell cycle control and cancer. Science 1994;266:1821-8.

13 Shinozaki H, Ozawa S, Ando N, Tsuruta $H$, Terada $M$, Ueda $M$, et al. Cyclin D1 amplification as a new predictive classification for squamous cell carcinoma of the esophagus, adding gene information. Clin Cancer Res 1995;2: 1155-61.

14 Naitoh H, Shibata J, Kawaguchi A, Kodama M, Hattori T. Overexpression and localization of cyclin D1 mRNA and antigen in esophageal cancer. Am F Pathol 1995;146:11619.

15 Sheyn I, Noffsinger AE, Heffelfinger S, Davis B, Miller MA, Fenoglio-Preiser CM. Amplification and expression of the cyclin D1 gene in anal and esophageal squamous cell carcinomas. Hum Pathol 1997;28:270-6.

16 Adelaide J, Monges G, Derderian C, Seitz JF, Birnbaum D. Oesophageal cancer and amplification of the human cyclin D gene CCND1/PRAD1. Br $\mathcal{f}$ Cancer 1995;71: 64-8. 